\title{
Feasibility and Estimation of Technical Potential and Calculation of Payback Period of Roof-Top Solar PV System in the City of Majmaah, Province of Riyadh, K.S.A
}

\author{
Ahmed-Bilal Awan ${ }^{1, ~ *}$, Taher Shaftichi ${ }^{1}$, Ahmed G. Abu-Khalil ${ }^{1,2}$ \\ ${ }^{1}$ Electrical Engineering Department, College of Engineering, Majmaah University, Majmaah, Saudi Arabia \\ ${ }^{2}$ Electrical Engineering Department, Faculty of Engineering, Assuit University, Assiut, Egypt
}

\section{Email address:}

a.awan@mu.edu.sa (Ahmed-Bilal A.)

\section{To cite this article:}

Ahmed-Bilal Awan, Taher Shaftichi, Ahmed G. Abu-Khalil. Feasibility and Estimation of Technical Potential and Calculation of Payback Period of Roof-Top Solar PV System in the City of Majmaah, Province of Riyadh, K.S.A. Journal of Energy and Natural Resources. Special Issue: Electrical Power Resources: Coal versus Renewable Energy. Vol. 5, No. 1-1, 2016, pp. 12-18. doi: 10.11648/j.jenr.s.2016050101.13

\begin{abstract}
Depletion of fossil fuels in near future and accumulation of their emissions in the environment have attracted the world's attention to utilize renewable resources of energy. Oil and gas are the two main sources of power generation in Kingdom of Saudi Arabia. The problem of energy security, the aspect of environmental pollution and depletion of the known fuel reserves in future have created a scope for utilization of renewable resources. In this paper, the most feasible method of rooftop solar PV power generation will be evaluated. A techno-economic feasibility of rooftop PV solar power generation for the city of Al-Majmaah province of Riyadh, KSA is performed.
\end{abstract}

Keywords: Renewable Energy, Solar Energy, Greenhouse Gases, PV, Solar PV

\section{Introduction}

Depletion of fossil fuels in near future and accumulation of their emissions in the environment have attracted the world's attention to utilize renewable resources of energy. It is realized that a continuous reliance on fossil fuels will have catastrophic results because excessive carbon dioxide emission has dramatic global warming effects. Our earth could heat up by several degrees in future if we do not stop using non-renewable energy resources. Environmental pollution is supposed to be a serious threat to life on the planet. Therefore use of green energy sources is spreading day by day through out the world. Fossil fuel burning results in emission of hazardous gases. Accumulation of these gases in the environment is a serious threat [1]. Scientific confirmation that $\mathrm{CO} 2$ emissions associated with fossil fuel energy combustion represent the largest source of greenhouse gas emissions from human activity [2, 3]. It is becoming increasingly evident that the level of $\mathrm{CO} 2$ emissions associated with fossil fuel combustion is so voluminous that an effective technical fix to the problem is inevitable [4-7]. Concerning oil, the Japanese government which oversees an oil dependent economy estimates that commercially recoverable reserves of oil will be exhausted in
40 years [8]. In terms of natural gas, the global reserves-toproduction ratio of natural gas has been estimated at 63-66 years [9]. In other words, many young people alive today might actually witness the depletion of these vital resources.

These concerns with fossil fuels have attracted the world's attention to utilize renewable resources of energy because of their environmental friendly features [10] and abundant availability. Renewable energy sources are inexhaustible, contrary to fossil fuels, and more widely spread over the Earth's surface $[11,12]$. The Sun being exceptional energy source, produces plentiful energy for the world. Energy produced by the Sun is in the form of electromagnetic radiation. Solar energy reaching the earth's surface averages to $1353 \mathrm{~W} / \mathrm{m} 2$ [13].

Commercial and residential buildings in Saudi Arabia consume about $50 \%$ of the total electrical energy consumed $[14,18]$. Increasing demand of electrical energy is one of the main problems being faced by the power companies in KSA. In order to meet this increasing demand of electricity in the country, it is desirable to explore every possible option of generating electric power. Saudi Arabia has enormous oil resources. At the same time, the Kingdom is blessed with other resources, notably solar energy that may be the future electric supply in the Kingdom. Green energy presents many 
potential advantages to KSA. Firstly, due to its abundant resources, the Kingdom has a viable option for domestic consumption that would save a large amount of oil for export. Secondly, the green energy reduces atmospheric pollution and greenhouse gases emissions. The monthly average daily solar radiation of KSA varies from 3.03-7.51 kwh/m2, which is one of the highest in the world [15]. Most of the countries around the globe are interested to penetrate the RE in their power sectors to obtain economic and environmental benefits.

Research is being conducted throughout the world for the development of sustainable, renewable and new energy efficient systems. The increase in population and the development of the Industrial sector in the Kingdom of Saudi Arabia have resulted in an alarming increase in the use of fossil fuels. Though KSA is an oil rich country and the cost of fossil fuel is very low but the costs associated with emissions (in the result of fossil fuels) may affect the economy of the country. Fossil fuels, although produce useful energy, are responsible for production of harmful emissions like $\mathrm{CO} 2$, SOx, NOx etc. The obvious choice available is to use renewable energy.

\section{Global Solar Generation}

The global share of renewable energy in the power sector was $20.3 \%$ at the end of year 2011 [16]. The hydroelectric generation being the oldest and most mature form of bulk power generation has a share of $15.3 \%$ whereas only $5 \%$ was contributed by other renewable generations [17].

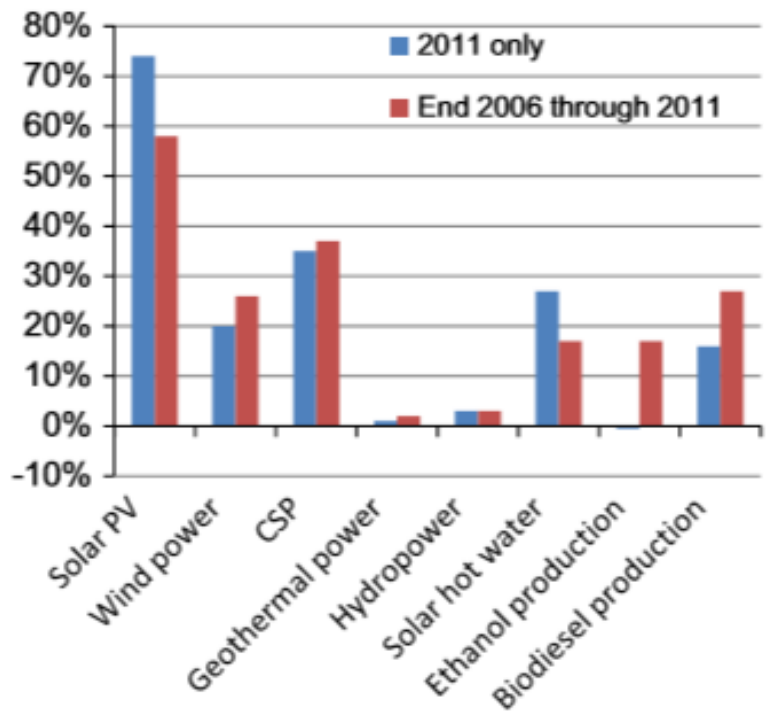

Fig. 1. Comparison of growth rates of renewable power generation.

The main methods of harnessing solar energy for power generation are solar thermal generation and Solar PV generation. Solar PV capacity has increased more rapidly during the last few years. The global installed capacity has increased from $2.2 \mathrm{GW}$ in 2002 to $70 \mathrm{GW}$ up to the end of year 2011 [16]. The growth rates of different renewable energy technologies between 2006 and 2011 are shown in the Fig. 1 [17] It is evident from Fig. 1 that Solar PV has the largest growth rate of $74 \%$ followed by CSP (35\%), solar water heating $(27 \%)$, wind power $(20 \%)$, biodiesel $(16 \%)$, hydropower $(3 \%)$, geothermal power $(1 \%)$ and ethanol production $(-0.5 \%)$.

There are various methods to harness the power of the Sun and generate electricity. Fig. 2 shows the different Solar Power Generation options. Fixed PV system has the least operation and maintenance (O\&M) costs. The tracking panel PV has intermediate output and O\&M costs. In this study the fixed flat panel PV option has been taken into account because of its simplest design and lowest cost.

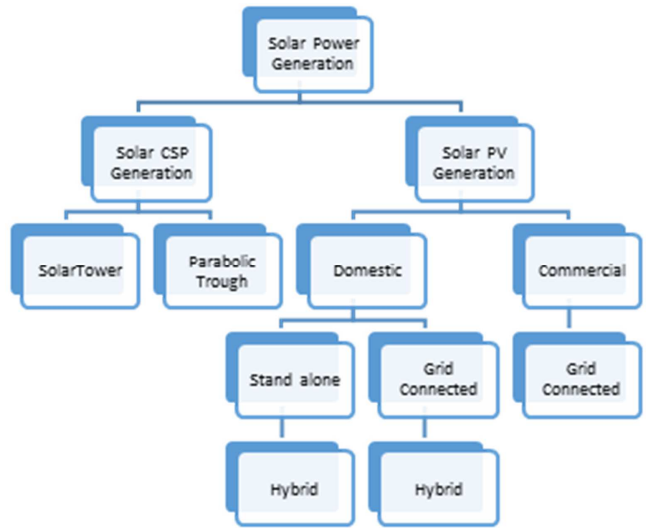

Fig. 2. Methods of Solar Power Generatins.

\section{Methodology Adopted to Evaluate the Most Feasible Method of Solar Power Generation}

The only viable method to evaluate the benefits of solar energy is the calculation and comparison of per unit cost of solar power generation. The crystalline silicon type are more efficient than the thin film type solar cells. Similarly the fixed flat panel PV has the lowest capital and maintenance costs. The tracking flat PV panel and concentrating PV(CPV) have more O\&M costs and are technologically less matured in comparison. It has been proved that output of fixed plate system is maximum when inclined at an angle equivalent to latitude of the location. Therefore the PV panel system under study is fixed tilt poly crystalline PV system. The per unit installation cost of solar power genaration is given by the following equation:

$$
\text { Cost }=\frac{\text { Total Cost during life span in } U S \$}{\text { Size of the installed system in } K W p}
$$

The most feasible method assesed by studying a $1 \mathrm{KW}_{\mathrm{p}}$ system which produces comparable results for other larger sizes of roof top PV systems and thus satisfy the objective of this research. The cost of system components was found through survey of the local market. The solar industry is progressing very fast and todays solar systems may become obsolete in 10 years, therefore the maufacturers are cautious when guarantees are concerned. The systems which have 25 years life time working warranties are German and Japanese. 
Therefore the cost of solar PV system has been taken from distributors of German and Japanese manufacturers because they provide around 25 years of warranties on the solar system components. Such PV systems have efficiencies of around $15 \%$ and are warranted that the output will decline by no more than $80 \%$ of the rated output in 25 years. The calculation of the solar PV system comnponents and their costs are discussed in the following sections.

\section{Size and Cost Calculations of PV Systems}

Some solar projects are over 40 years of age and are still providing power. But solar projects are generally designed for an estimated life span of around 25 years. The Total Life Cycle Cost (TLCC) is given by:

\section{TLCC $=$ Fixed charges + variable charges}

\section{Fixed charges $=$ Upfront cost}

The upfront cost is the aggregate costs of system components required to initiate the project.

$$
\text { Cost }_{\text {upfront }}=\text { Cost }_{\text {panels }}+\text { Cost }_{\text {inverter }}+\text { Cost }_{\text {batteries }}
$$

Variable charges include operartion and maintenance (O\&M) costs and cost of replacement of batteries, inverters, charge controllers etc. during the life cycle. For a fixed tilt system the O\&M charges are negligible, and battery and other components replacement charges are given by:

Variable charges

= Cost of system component replacements during life period

\subsection{Size of PV panels}

Peak power delivered by PV panels is:

$$
P_{\text {peak,panels }}=\text { No. of Panels } \times \text { Power per Panel }
$$

It is not necessary for $P_{\text {peak, usage }}$ to be equal to $P_{\text {peak, panels }}$ since both the output and requirements change throughout the year. But inorder to maximize the benefits, the energy produced by solar panels should be equal to energy utilized. i.e $E_{\text {panels }}=E_{\text {used }}$

$$
\begin{gathered}
\text { Peak power produced by panels }=P_{\text {peak,panels }}=\frac{E_{\text {used }}}{T_{\text {sun }}} \\
T_{\text {sun }}=\text { No. of hours of Sun shine } \\
\text { Cost of pannels }=\text { Cost } t_{\text {panels }} \\
=\text { No. of Panels } \times S C_{\text {panels }} \\
S C_{\text {panels }}=\text { panel specific cost in US dollars }
\end{gathered}
$$

A more specific way to ensure solar power availability is to calculate the minimum solar power generation and then design a solar PV system that can support the required load even during the minimum generation period. The solar PV is tested to produce rated output under Standard Testing Conditions (STC): $1000 \mathrm{~W} / \mathrm{m}^{2}$ solar irradiance, 1.5 Air Mass and cell temperature of $25^{\circ} \mathrm{C}$. From Table-I, it can be easily seen that the solar generation is minimum in June and can be upto $603.05 \mathrm{Watt} / \mathrm{m}^{2} / \mathrm{hr}$. There are many varieties of solar $\mathrm{PV}$ available in the market from $30 \mathrm{~W}$ to $250 \mathrm{~W}$. After survey of market, Poly-crystalline PV with $250 \mathrm{~W}, 12 \mathrm{~V}$ ratings and dimensions of $1650 \times 100 \mathrm{~mm}\left(1.65 \mathrm{~m}^{2}\right)$ has been selected. Now the number of PV panels required for $1 \mathrm{KW}_{\mathrm{p}}$ load can be calculated as in Table-II. Table-II depicts that surplus power will be available that could be used locally, stored or fed to utility for utilization during the months with irradiance higher than $603.05 \mathrm{~W} / \mathrm{m}^{2}$. Selection of smaller PV size than required will result in decrease of battery life and shut down of PV system by the inverter when voltage reach cut-off value; with no backup for cloudy days.

Table 1. Detail of Solar power irradiance collected in Riyadh/Majmaah.

\begin{tabular}{llllllll}
\hline Month & $\mathbf{G}_{\mathbf{k}}$ Hor $\mathbf{K W h} / \mathbf{m}^{2}$ & Days & Sun Hours & $\mathbf{K W h} / \mathbf{m}^{2} / \mathbf{d a y}$ & $\mathbf{K W} / \mathbf{m}^{2} / \mathbf{h r}$ & $\mathbf{W} / \mathbf{m}^{2} / \mathbf{d a y}$ & $\mathbf{W} / \mathbf{m}^{2} / \mathbf{h r}$ \\
\hline Jan & 174.3 & 31 & 7.2 & 5.62 & 0.78 & 5622.58 & 780.55 \\
Feb & 177.3 & 28 & 8.0 & 6.33 & 0.79 & 6332.14 & 791.25 \\
Mar & 209.4 & 31 & 7.0 & 6.75 & 0.96 & 6754.84 & 964.28 \\
Apr & 186.6 & 30 & 8.2 & 6.22 & 0.76 & 6220.00 & 758.53 \\
May & 201.1 & 31 & 9.03 & 6.49 & 0.72 & 6487.09 & 721.11 \\
Jun & 201.9 & 30 & 11.16 & 6.73 & 0.60 & 6730.00 & 603.05 \\
Jul & 211.2 & 31 & 11.13 & 6.81 & 0.61 & 6812.90 & 611.85 \\
Aug & 217.0 & 31 & 10.16 & 7.00 & 0.69 & 7000.00 & 688.97 \\
Sep & 219.0 & 31 & 8.55 & 7.31 & 0.85 & 7064.52 & 854.97 \\
Oct & 222.2 & 30 & 10.33 & 7.16 & 0.69 & 7406.66 & 693.12 \\
Nov & 179.6 & 31 & 8.53 & 5.99 & 0.70 & 5793.55 & 702.23 \\
Dec & 168.6 & 30 & 7.03 & 5.43 & 0.77 & 5620.00 & 772.40 \\
Total/Average & 2368.2 & 365 & 8.86 & 6.49 & 0.74 & 6487.02 & 745.19 \\
\hline
\end{tabular}


Table 2. Size Calculassions of PV panels.

\begin{tabular}{ll}
\hline Area of One PV Panel & $=1.65 \mathrm{~m}^{2}$ \\
Solar irradiance under STC to produce rated output of $250 \mathrm{~W}$ & $=1650 \mathrm{~W}$ \\
Thus the efficiency of the solar panel & $=15.15 \%$ \\
Min.solar irradiance expected in June & $=603.05 \mathrm{~W} / \mathrm{m}^{2}$ \\
Min. solar irradiance expected in June for panel with $1.65 \mathrm{~m}^{2}$ area & $=603.05 \times 1.65$ \\
& $=995.03 \mathrm{~W}$ \\
Min. generation of each solar panel during June & $=995.03 \times 15.15 \%$ \\
No. of PV panels required to meet load demand of $1 \mathrm{KWp}$ & $=151 \mathrm{~W}$ \\
Similarly the max. solar irradiance expected in the month of March & $=1000 / 151=7 \mathrm{No}$. \\
Max. solar irradiance expected in March for panel with $1.65 \mathrm{~m}^{2}$ area & $=964.28 \mathrm{~W} / \mathrm{m}^{2}$ \\
The max. generation of solar panels during March & $=964.28 \times 1.65$ \\
Max generation from 07 No. Solar PV panels in March & $=1591.06 \mathrm{~W}$ \\
& $=1591.06 \times 15.15 \%$ \\
& $=241 \mathrm{~W}$ \\
& $=241 \times 7=1687 \mathrm{~W}$ \\
\hline
\end{tabular}

\subsection{Size of Charge Controller}

The output of the PV panels vary due to change in weather conditions. The charge controller controls and maintains the current from the panels to the batteries. It is rated in amperes and is designed in accordance with the output voltage of the panels. They convert the dc output of the panel to ac and then back again to dc to feed regulated supply to the batteries They are around $95 \%-97 \%$ efficient. The charge controllers protect the batteries from being overcharged. They also protect the PV panels from the back flow of charge from the batteries. For both Off-grid and on On-grid systems, the size of the controller depends on the short circuit current ratings $\left(\mathrm{I}_{\mathrm{sc}}\right)$ of the panels, which is $8.5 \mathrm{~A}$ for the selected panels. The controllers must have spare capacity since it is not a good idea to use them at full capacity. During cool sunny days, the output of the panels can increase the rated output by $25 \%$. Since the panels are connected in parallel, therefore the size of charge controller can be calculated by:

Size of charge controller $=\mathrm{I}_{\mathrm{sc}} \times$ No of panels $\times 1.25$

$$
\begin{aligned}
& =8.5 \times 7 \times 1.25 \\
& =74 \mathrm{~A} \text { or } 100 \mathrm{~A} \text { approx }
\end{aligned}
$$

$\mathrm{I}_{\mathrm{sc}}=$ Short circuit current of pannel

\subsection{Size of Batteries}

To keep the upfront cost to minimum, we are designing the PV system for a backup of one day only. The life of a battery is a function of amount of battery discharge in percentage. This is also known as depth of discharge (Dod). For instance, a battery allowed to discharge $20 \%$ only will have more life as compared to that allowed to discharge $40 \%$. The dry batteries can be discharged upto $70 \%$ with the output voltage and temperature of the cells in permissible limits. The batteries themselves are around $85 \%$ efficient. First the voltage and size of batteries in apmere hours (Ah) is selected. For systems with longer cables and high load, 24V or $48 \mathrm{~V}$ system may be adopted to minimize the losses. But for smaller systems, the $12 \mathrm{~V}$ system provides a simple solution. Therefore dry batteries of $200 \mathrm{Ah}, 12 \mathrm{~V}$ that could be discharged upto $70 \%$ without decline in their rated output voltage have been selected for the study. The number of batteries required can be calculated from the following formula:

$$
\mathrm{N}_{\text {B-req }}=\frac{\text { Wh load }}{\left(V_{b} \times \eta_{b} \times \operatorname{Dod} \times A h_{b}\right)} \times \text { No. of days }
$$

For a load of $1 \mathrm{KW}$ the energy required at $40 \%$ load factor $=1000 \times 24 \times 40 \%=9600 \mathrm{Wh} /$ day

No of batteries required for an off-grid system with one day backup (incase of cloudy horizon) = $\frac{9600 \mathrm{Wh}}{(12 \mathrm{~V} \times 0.85 \times 0.7 \times 200)} \times 1=6.7=7$ batteries

Similarly, for an on-grid system the backup required to cope with an occusional electrcity cut of 4 hours = $\frac{9600 \mathrm{Wh}}{(12 \mathrm{~V} \times 0.85 \times 0.7 \times 200)} \times 0.167=2$ batteries

This concludes that for an off-grid PV system of $1 \mathrm{KW}_{\mathrm{p}}$, around 7 batteries of $200 \mathrm{~A}$ will supply one day backup (in case of cloudy wheather), whereas 2 batteries are required to provide 4hours of continuous backup in an on-grid solar PV system. In an off grid system the batteries will be replaced after every five years. Whereas in an on-grid system, the battery sets will be replaced after every six years owing to increase in life due to less frequency of charging and discharging.

\subsection{Size of Inverter}

In an Off-gird solar PV system, the peak power delivered by the inverter should be equal to peak power usage i.e.

$$
P_{\text {peak,inverter }}=P_{\text {peak,usage }}
$$

Considering a load factor of $40 \%$, the load is $400 \mathrm{~W}$ for a $1 \mathrm{KW}$ system.

$$
\text { size of inverte }=\operatorname{load}(W) \times 1.3=400 \times 1.3=520 \mathrm{~W}
$$

In view of available solar power and possibility of future extension in load a $1 \mathrm{KW}$ inverter is recommended for Off- 
grid system. In an On-Grid system, the inverters not only have to confront the above load but also has to redirect the additional solar generation to the grid. The charge controllers are around $97 \%$ efficient at the most, the batteries can produce $85 \%$ of their input and the inverters themselves are around $90 \%$ efficient. If $2 \%$ drop in the cables is taken into account, the efficiency of the system (excluding efficiency of the panels) calculates to around $0.727 \%$ as follows:

$$
\eta_{\text {sys }}=0.98 \times 0.97 \times 0.85 \times 0.9=0.727 \%
$$

The max. power $\left(\mathrm{P}_{\max }\right)$ supplied by the solar system is therefore:

$$
\begin{gathered}
\left.P_{\text {max }}=250 \mathrm{~W} \times 7 \text { (no. of panels }\right) \times 0.727 \\
=1272.25 \text { Watts }
\end{gathered}
$$

Considering spare capacity for motive loads, the size of the inverter to be selected is around $2000 \mathrm{~W}$.

\section{Cost Comparison of Solar PV Systems}

Saudi Arabia can save oil by generating electricity using Solar PV and as a result, can export more oil in international market. Saudi Arabia is an oil rich country and domestic oil prices are very low. Power generation in the country mainly comes from oil and gas power plants. A cost comparison is presented in this section to see the effectiveness of solar PV generation. According to U.S. DOE's EIA, 1.8barrels of oil is required to generate $1 \mathrm{MWh}$ of electricity [18]. The domestic price of oil charges to Saudi Electricity companty is $\$ 0.73 / \mathrm{mmBTU}$ or $\$ 4.1 /$ barrel [18]. Therefore, cost of electicity for an oil based power plant in Saudi Arabia is $\$ 7.8$ per MWh. There is some additional O\&M cost which is assumed to be $\$ 5.39$ per $\mathrm{MWh}$. These figure are very difficult to beat but use of rooftop solar PV is still a very good alternative. Around $50 \%$ of the generated electricity in KSA is being used by residentiol consumer. Therefore use of rooftop solar PV will save huge amount of oil which could be exported in international market and in this way Kingdom can earn revenue and sustain as a leading oil export country for longer time. A cost of crude oil in internation market is $\$ 61.0 /$ barrel as of today. For each MWh of electricity, the country can save 1.8 barrel of oil which is equivalent to $\$ 110$ in internation market. According to these international rates the cost of electricity production is:

$$
\begin{gathered}
\text { Cost per } M W h=61.0 \times 1.8+O \& M \text { cost } \\
=110+5.39=\$ 115.19 \\
\text { Cost per KWh }=\$ 0.115
\end{gathered}
$$

For the cost comparison, the existing solar solution provider companies were surveyed in this matter and the cost of equipment with extended warranties during the entire term of the project was found. The component wise cost of a 1 $\mathrm{KW}_{\mathrm{p}}$ system is detailed in Table-III. The only difference between the off-grid and on-grid system is the net metering cost and hence increase in labor installation. Addition of batteries further increase the labor cost. The output of solar PV system in converted into energy value in US dollars according to oil prices in the international market. It had been observed that oil prices are showing an annual rise of $3 \%-8 \%$ per year in the last two decades. We assumed the minimum rise of $3 \%$ in our calculations over the life span of the project. Table IV indicates the energy value per year and the accumulative returns or payback. The payback period of each method is as under:

- Payback period of Off-grid rooftop solar PV system without batteries is 12 years

- Payback period of On-grid rooftop solar PV system without batteries is 13 years

\begin{tabular}{|c|c|c|c|c|c|c|c|}
\hline \multirow[b]{2}{*}{ Cost Type } & \multirow[b]{2}{*}{$\begin{array}{l}\text { System } \\
\text { Components / } \\
\text { Equipment }\end{array}$} & \multirow[b]{2}{*}{$\begin{array}{l}\text { Quantity required for } 1 \\
\mathrm{KW}_{\mathrm{p}} \text { roof-top solar PV } \\
\text { system }\end{array}$} & \multicolumn{5}{|c|}{ Cost of Solar System in US\$ } \\
\hline & & & $\begin{array}{l}\text { Per Unit } \\
\text { Estimated } \\
\text { Cost (US \$) }\end{array}$ & $\begin{array}{l}1 \mathrm{KWp} \text { Off- } \\
\text { grid without } \\
\text { batteries } \\
\text { (US \$) } \\
\end{array}$ & $\begin{array}{l}\text { 1KWp Off- } \\
\text { grid with } \\
\text { batteries } \\
\text { (US \$) }\end{array}$ & $\begin{array}{l}1 \mathrm{KWp} \text { On- } \\
\text { grid without } \\
\text { batteries } \\
\text { (US \$) } \\
\end{array}$ & $\begin{array}{l}\text { 1KWp On- } \\
\text { grid with } \\
\text { batteries } \\
\text { (US \$) }\end{array}$ \\
\hline \multirow{5}{*}{$\begin{array}{l}\text { Installation } \\
\text { Cost / } \\
\text { Upfront Cost } \\
\text { or Fixed Cost }\end{array}$} & Solar Panel & 07 No (250 $\mathrm{W}_{\mathrm{p}}$ PV panels) & $2.13 / \mathrm{W}$ & 3733 & 3733 & 3733 & 3733 \\
\hline & Charge controller & $01 \mathrm{No}$ & 2.7/Amp & - & 270 & - & 270 \\
\hline & Invertor & $\begin{array}{l}01 \mathrm{No} \text { (1 KW for Off-Grid) } \\
\text { (2 KW for On-Grid) }\end{array}$ & $0.135 / \mathrm{W}$ & 135 & 135 & 270 & 270 \\
\hline & Batteries & 07 No Off-Grid & $0.93 / \mathrm{Ah}$ & - & 1302 & - & 375 \\
\hline & $\begin{array}{l}\text { BOS (Cost of } \\
\text { frames, cables, } \\
\text { installation cost, } \\
\text { transport cost, net } \\
\text { metering cost etc.) }\end{array}$ & Once & 500 to 800 & 500 & 600 & 700 & 800 \\
\hline Variable Cost & Batteries & one set after every 5 years & $0.93 / \mathrm{Ah}$ & - & $\begin{array}{l}1302 \times 4= \\
5208\end{array}$ & - & $\begin{array}{l}375 \times 4= \\
1500\end{array}$ \\
\hline Total cost & - & - & - & 4,338 & 11,248 & 4,703 & 6,948 \\
\hline
\end{tabular}

- Payback period of On-grid rooftop solar PV system with batteries is 17 years

- Payback period of Off-grid rooftop solar PV system with batteries is 25 years

Table 3. Cost of Solar PV Power System. 
The cheapest solution for roof-top solar power generation at domestic level is Off- grid without batteries. But there is no other backup than solar power and the reliability of this system is least. To create a back-up source, batteries are required in an off-grid system for use in the evening and night and backup for cloudy days. But this makes the Offgrid system with batteries, the most expensive solar PV system. Similarly when the solar power generation is more than demand or someone has the capability to install a solar system of higher capacity than his load requirements, the surplus generation will go waste. Therefore to maximize the benefits of solar power generation, the most feasible solar power method for solar power generation would be On-Grid without batteries. The per unit installation costs are comparable but the benefits expected with On-Grid solar PV system without batteries are far more. The payback period of this system is 13 years.

Table 4. Payback period of Solar PV system.

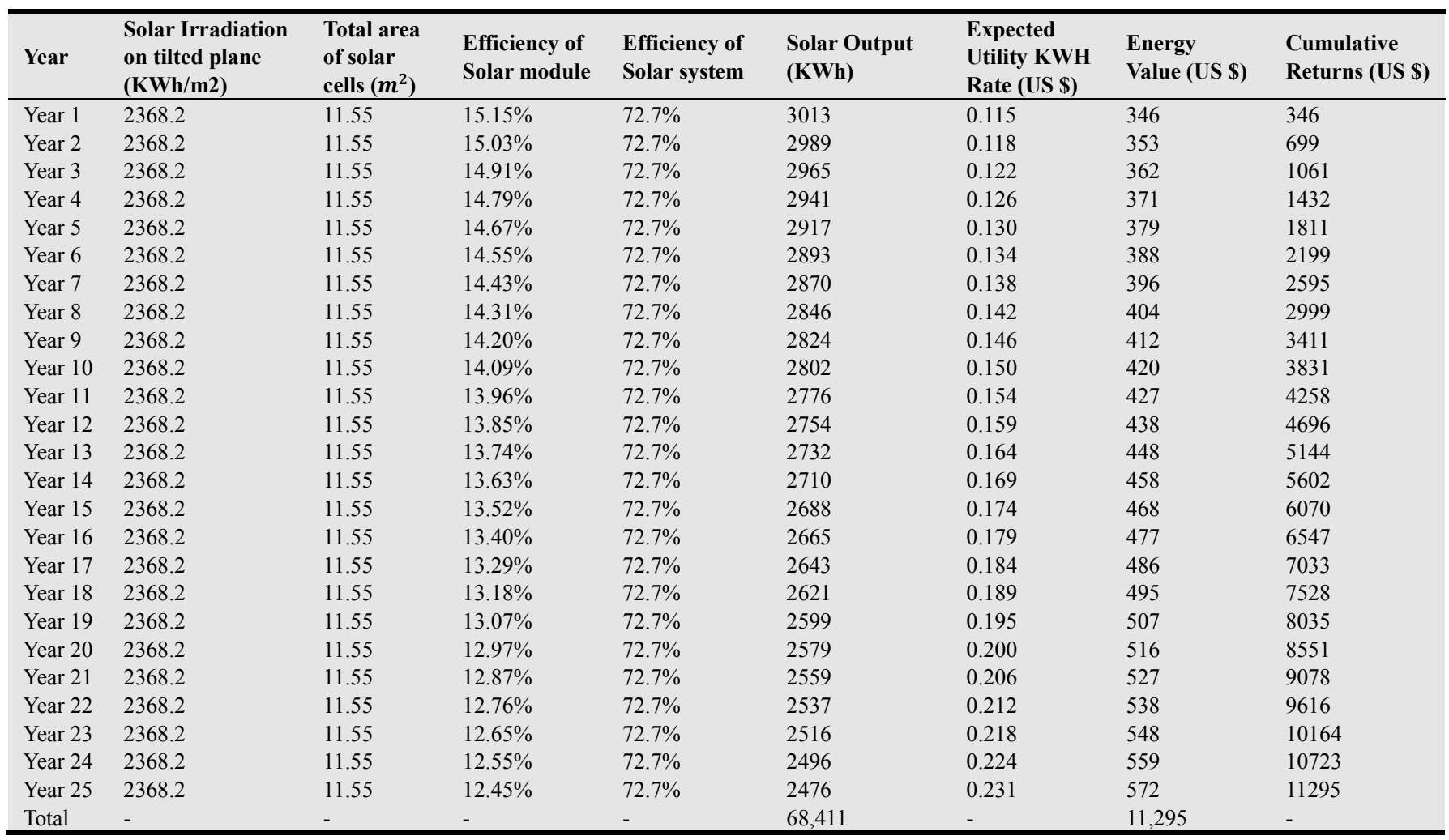

\section{Conclusion}

The purpose of this research is to optimize the power generation cost while reducing hazardous emissions. Feasibility of rooftop solar PV system in Riyadh region in Kingdom of Saudi Arabia is evaluated in this paper and the most feasible method of rooftop solar PV power generation is evaluated. A comparison of various solar PV generation options is conducted by studying their design in detail and finally the payback periods is calculated in light of costs and benefits of each project. It is found that On-grid rooftop solar PV system without batteries is the most feasible system from both reliability and econimical point of view.

\section{References}

[1] G. W. Crabtree and N. S. Lewis, "Solar Energy Conversion," Physics Today, vol. 60, pp. 37-42, 2007.
[2] Chalvatzis KJ, Hooper E. Energy security vs. climate change: theoretical framework development and experience in selected EU electricity markets. Renew Sust Energy Rev 2009; 13: 2703-9.

[3] IPCC. Climate change 2007: synthesis report. Geneva, Switzerland: Intergovernmental Panel on Climate Change (IPCC); 2007.

[4] Bruggink JJC, Van Der Zwaan BCC. The role of nuclear energy in establishing sustainable energy paths. Int J Global Energy Issues 2002; 18: 151-80.

[5] Trainer T. Can renewables etc. solve the greenhouse problem? The negative case. Energy Policy 2010; 38: 4107-14.

[6] Stern N. The global climate change imperative. 2007: 90.

[7] Zidansek A, Blinc R, Jeglic A, Kabashi S, Bekteshi S, Slaus I. Climate changes, biofuels and the sustainable future. Int $\mathrm{J}$ Hydrogen Energy 2009; 34: 6980-3.

[8] ANRE. Energy in Japan 2006: Status and Policies. Tokyo, Japan: Agency for Natural Resources and Energy, Japan Ministry of Economy, Trade and Industry (ANRE); 2006. pp. $1-28$. 
[9] EIA. International Energy Outlook 2008. Washington, USA: Energy Information Administration, U.S. Department of Energy; 2008, p. 1-260.

[10] G. W. Crabtree and N. S. Lewis, "Basic research needs for solar energy utilization," 2005.

[11] Braun FG, Hooper L, Wand R, Zloczysti P. Innovation in concentrating solar power technologies: a study drawing on patent data. Discussion papers. Berlin: DIW Berlin, German Institute for Economic Research; 2010.

[12] Amita Ummadisingu, M.S. Soni, Concentrating solar power Technology, potential and policy in India, Renewable and Sustainable Energy Reviews, Volume 15, Issue 9, December 2011, Pages 5169-5175, ISSN 1364-0321.

[13] Goswami, D. Yogi, Kreith, Frank, and Kreider, Jan F., Principles of Solar Engineering, 2nd edition. Taylor and Francis, Philadelphia, PA, 2000.

[14] Shaahid SM, Elhadidy MA. Economic analysis of hybrid photovoltaic-diesel-battery power systems for residential loads in hot regions - a step to clean future. Renewable and Sustainable Energy Reviews 2008; 12: 488-503.
[15] S.M. Shaahid, L.M. Al-Hadhrami, M.K. Rahman, Review of economic assessment of hybrid photovoltaic-diesel-battery power systems for residential loads for different provinces of Saudi Arabia, Renewable and Sustainable Energy Reviews, Volume 31, March 2014, Pages 174-181, ISSN 1364-0321.

[16] Renewables 2012 Global Status Report. (http://www.map.ren21.net/GSR/GSR2012_low.pdf).

[17] Ahmad Bilal Awan, Zeeshan Ali Khan, Recent progress in renewable energy - Remedy of energy crisis in Pakistan, Renewable and Sustainable Energy Reviews, Volume 33, May 2014, Pages 236-253, ISSN 1364-0321.

[18] Kaffine Daniel T, McBee, Brannin J, Lieskovsky, Jozef, Emissions Savings from Wind Power Generation in Texas, The Energy Journal, Volume 34, Issue 1, January 2013, Page 155.

[19] Ali Ahmad, M.V. Ramana, Too costly to matter: Economics of nuclear power for Saudi Arabia, Energy, Volume 69, 1 May 2014, Pages 682-694, ISSN 0360-5442. 